\title{
Herbicide runoff from a soil with different levels of sugarcane straw coverage in Brazil
}

\author{
Trovato, V.W.'; Portilho, I.I.R. ${ }^{1}$; Barizon, R.R.M. ${ }^{2} \&$ Scorza Júnior, R.P..$^{*}$ \\ ${ }^{1}$ Programa de Pós-Graduação em Recursos Naturais, Universidade Estadual de Mato Grosso do Sul, Dourados, MS, Brazil. \\ ${ }^{2}$ Embrapa Meio Ambiente, Jaguariúna, SP, Brazil. \\ ${ }^{3}$ Embrapa Agropecuária Oeste, Dourados, MS, Brazil. P.O Box 449, CEP 79804-970.
}

Received July 02, 2019; Accept June 09, 2020

\begin{abstract}
This study evaluates the effects of different levels of sugarcane straw on the soil surface on the transport by runoff water of four herbicides: ametryn, diuron, hexazinone, and sulfentrazone. Two runoff experiments were conducted in a set of nine experimental plots. In the first experiment, sugarcane was cultivated and no straw was applied to the soil. In the second experiment, sugarcane was cultivated with straw levels of 0,9 , or $18 \mathrm{Mg} \mathrm{ha}^{-1}$ on the soil surface. The runoff water from natural rainfall was collected in reservoirs at the lower end of each plot on different occasions following the application of the herbicides to the plots. The total volume of runoff water collected from the plots was dependent on the coverage of the soil by straw, in the sequence: $0>9>18 \mathrm{Mg} \mathrm{ha}^{-1}$. For the herbicides hexazinone and sulfentrazone, which are molecules of high solubility in water, increasing the amount of straw on the soil produced an increase in the fraction of the applied dose appearing in the collected runoff water. However, for diuron and ametryn, which have low solubility in water, the presence of straw did not influence the amount found in the collected runoff water.
\end{abstract}

Keywords: Environmental exposure, herbicide transport, pesticide behavior.

\section{INTRODUCTION}

Changes in the sugarcane harvesting system, in which the burning of the leaves from the canes prior to manual collection has been replaced by mechanized stripping of the leaves from the canes as they are harvested, has promoted a significant increase in the amount of plant residues deposited on the soil. The estimated amount of straw deposited on the soil surface after mechanized harvesting ranges from 7.4 to $24.3 \mathrm{Mg} \mathrm{ha}^{-1}$ (Paes \& Oliveira, 2005). The retention of these residues on the fields after harvesting has multiple benefits, including a reduction in soil erosion by water, improved soil moisture conservation, as well as increases in soil organic carbon content, microbial diversity and activity (Bordonal et al. 2018).

The presence of straw on the soil surface may influence the behavior of herbicides applied to the field after the sugarcanes are harvested, such as their retention and leaching (Giori et al. 2014; Pereira-Junior et al. 2015). The interception of pesticides by the straw can lead to their retention in the plant residue layer above the soil, where they will be exposed to conditions likely to promote their dissipation, through processes such as photodegradation and volatilization, until they are transported into the soil by rainfall (Locke \& Bryson 1997). The role of the straw in the horizontal transport and hence dissipation of a pesticide following rainfall also requires consideration. Thus, a herbicide molecule retained in the straw may be transported from the field in surface water runoff at a different rate than a molecule that has arrived at the surface of the soil (Araldi et al. 2015). The rainfall intensity and the presence of sugarcane straw, as well as the interval between the application of the pesticide and the first rainfall, are all factors that can alter the dynamics of the dissipation of a pesticide, influencing both transport routes and fates (Carbonari et al. 2010). 
In the last few years, the production of sugarcane has expanded significantly in Mato Grosso do Sul (MS), a state located in central Brazil, so that the area planted with sugarcane has increased from 99,000 ha in 2000 to 658,000 ha in 2016 (IBGE 2018). Commensurate with this increase in production, there has been higher consumption of the pesticides associated with this crop. An increase in pesticide use invariably generates concerns over the environmental fate of these products. In particular, the main exposure route of surface water to pesticides is through the horizontal transport of these substances by runoff. Existing studies have shown that the retention of herbicides within a layer of sugarcane straw depends not only the quantity of rain falling on the straw but also on the molecule, pointing to the importance of molecule-straw interactions. Correia et al. (2013) verified that for sulfentrazone, $20 \mathrm{~mm}$ of rainfall, received shortly after the application of the herbicide on the straw, was sufficient to transfer the molecule from the straw to the soil. Araldi et al. (2015) evaluated the interaction of the herbicides atrazine, clomazone, diuron, hexazinone, metribuzin, and pendimethalin with sugarcane straw (10 $\left.\mathrm{Mg} \mathrm{ha}^{-1}\right)$ under simulated rainfall (5, $10,20,50$, and $100 \mathrm{~mm}$ ), and concluded that the percentage of herbicide transported across the straw layer was dependent on the physicochemical characteristics of the molecule.

The diversity of factors and interactions influencing herbicide runoff from soils covered with sugarcane straw shows the need for studies to be conducted that examine different herbicides, climatic conditions, soil types, and other factors likely to influence horizontal transport from fields. Studies on herbicide runoff from soils with the presence of sugarcane straw in the state of Mato Grosso do Sul (MS) were not found in the literature. In a recent literature review of plotscale runoff and soil erosion studies in Brazil, Anache et al. (2017) cite only five studies conducted in MS, none of which examined the surface runoff of pesticides. Therefore, the objective of the present study was to evaluate the influence of sugarcane straw on the runoff of ametryn, diuron, hexazinone, and sulfentrazone herbicides from an Oxisol in Dourados, MS. These four herbicides were selected due to their high use in sugarcane areas of MS and also due to their contrasting water solubility and half-life values in soil, which are important pesticide properties that can lead to different environmental behavior in soil and water.

\section{MATERIALS AND METHODS}

\section{Experimental area and herbicide application}

Nine experimental plots $(20 \mathrm{~m} \times 2 \mathrm{~m})$ were installed in a very clayey Oxisol (distrophic Haplorthox) (Santos et al., 2006) with a 3\% slope in February 2015 in an experimental area of the site occupied by Embrapa Agropecuária Oeste (geographical coordinates: $22^{\circ} 16^{\prime} 26.6^{\prime \prime} \mathrm{S} ; 54^{\circ} 48^{\prime} 50.6^{\prime \prime} \mathrm{W}$ ), located in Dourados, MS, Brazil (Figure 1). Reservoirs (1000 L) were set up at the lower end of each plot to collect the runoff water (Figure 1A).

Two runoff experiments were conducted in the set of nine experimental plots. For the first experiment (Experiment A), sugarcane was cultivated and no straw was applied to the soil, thereby simulating the raising of sugarcane in bare plowed soil, and there were nine replicate systems. In the second experiment (Experiment B), performed one year later, sugarcane was also cultivated in three treatments, corresponding to $0,50 \%$, and $100 \%$ coverage of the soil surface by sugarcane straw, achieved by homogeneously applying straw to the soil at rates of 0,9 , and $18 \mathrm{Mg} \mathrm{ha}^{-1}$, respectively. The straw was collected from sugarcane fields in Dourados, MS, and dried for 16 days in a greenhouse before distribution over the plots. The treatments were randomly assigned to the nine plots within the experimental area, so that there were three replicate systems for each treatment. The straw was allowed to stand on the soil for 20 days before the herbicides were applied to the plots.

The four herbicides, ametryn, diuron, hexazinone, and sulfentrazone, were applied separately, after dispersion in water, using a backpack sprayer at a volume application rate of $250 \mathrm{~L} \mathrm{ha}^{-1}$. The herbicide concentrations in the aqueous dispersions were selected to give active ingredient application

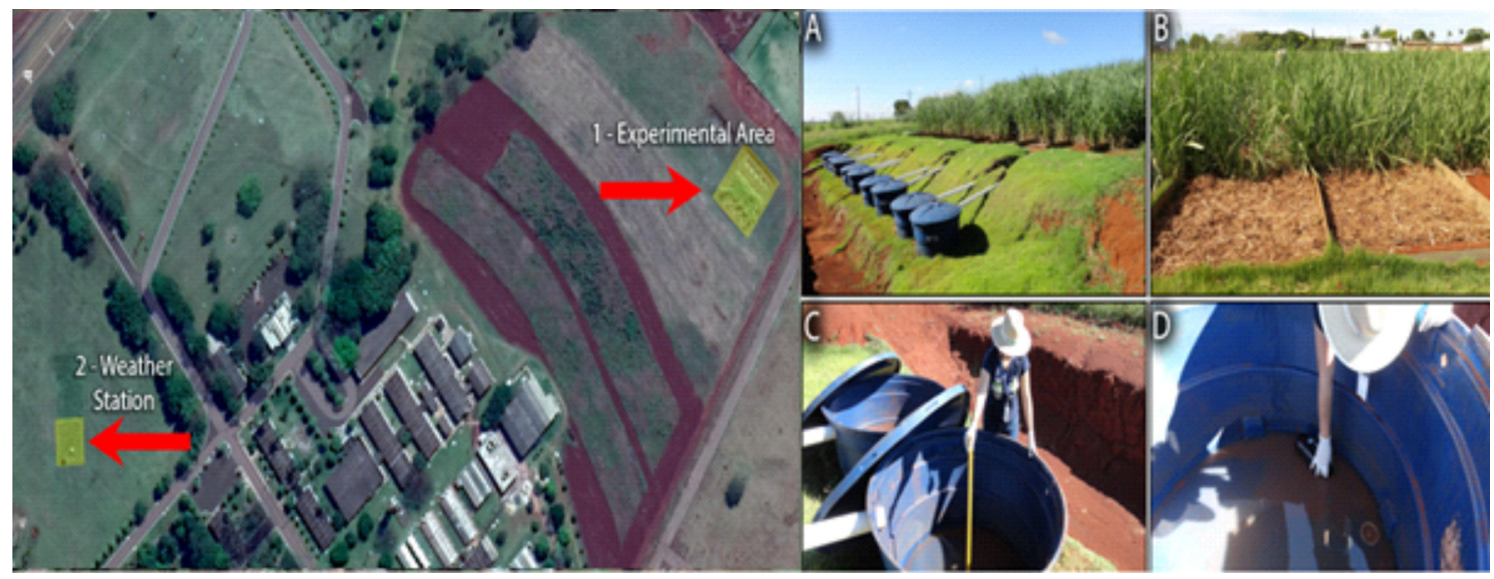

Figure 1. Satellite photograph of Embrapa Agropecuária Oeste in Dourados, MS, Brazil, showing the location of the weather station and the experimental plots (Source: Google Maps, accessed 14 February, 2019). A - Reservoirs to collect water from surface runoff; B - Sugarcane straw on the experimental plots; C - Measurement of the volume of runoff water; D - Collection of a sample of the runoff water. 
rates of $4.0 \mathrm{~kg} \mathrm{ha}^{-1}, 3.2 \mathrm{~kg} \mathrm{ha}^{-1}, 0.4 \mathrm{~kg} \mathrm{ha}^{-1}$, and $0.6 \mathrm{~kg} \mathrm{ha}^{-1}$, for ametryn, diuron, hexazinone, and sulfentrazone, respectively, which are within the recommended doses for sugarcane cultivation. Key physicochemical characteristics of the herbicide molecules, selected for their potential importance in the dissipation and transport of the herbicides, are presented in Table 1.

\section{Meteorological observations}

Meteorological data were collected automatically from a station within the Embrapa Agropecuária Oeste site, located about $500 \mathrm{~m}$ from the experimental area (Figure 1). In addition to collecting daily rainfall totals, the meteorological station provided the weather data necessary to calculate the reference crop evapotranspiration, $E T_{o}$, for each day, from the FAO Penman-Monteith equation (Allen et al., 1998).

\section{Runoff water}

For each sampling day, the volume of water collected in the reservoir at the end of each plot was determined by measuring the water level, and converting the level to a volume through an experimentally determined calibration. The water in the reservoir was completely homogenized by agitation, before a $1 \mathrm{~L}$ sample was withdrawn and transferred to an amber glass bottle. The collected samples of runoff water were stored in a refrigerator at $4{ }^{\circ} \mathrm{C}$ prior to analysis for the four applied herbicides. The water remaining in the reservoir was then discarded, leaving the reservoir ready to receive water until the next collection day.

\section{Quantification of herbicide residues in the runoff water}

The extraction and quantification of ametryn, diuron, hexazinone, and sulfentrazone in the runoff water was based on a method developed by Scorza Jr. (2015). A $150 \mathrm{~mL}$ aliquot of a runoff water sample was filtered under gravity through a qualitative filter paper, and the $\mathrm{pH}$ of the aliquot was then adjusted to 3 by adding hydrochloric acid solution (12 $\mathrm{mol} \mathrm{L}^{-1}$ in ultrapure water). The pesticide residues were extracted from the acidified water by liquid-liquid partition into dichloromethane. $100 \mathrm{~mL}$ of the acidified aliquot of runoff water were transferred to a separating funnel, and $100 \mathrm{~mL}$ of dichloromethane were added. Following vigorous shaking for two minutes, the dichloromethane fraction was

Table 1. Application rates and concentrations, and key physicochemical properties of the four herbicides, taken from the Pesticide Properties Database (PPDB, University of Hertfordshire, 2016).

\begin{tabular}{|c|c|c|c|c|c|c|c|c|c|}
\hline \multirow[b]{2}{*}{ Herbicide } & \multicolumn{2}{|c|}{ Application } & $\begin{array}{c}\text { Vapor } \\
\text { pressure }\end{array}$ & \multirow[b]{2}{*}{$\begin{array}{c}\mathrm{K}_{\mathrm{oc}} \\
\left(\mathrm{L} \mathrm{kg}^{1}\right)\end{array}$} & \multirow{2}{*}{\multicolumn{2}{|c|}{$\begin{array}{l}\text { Solubility in } \\
\text { water } \\
\left(\mathrm{mg} \mathrm{L}^{-1} \text { at } \mathrm{pK}_{\mathrm{a}}\left(25^{\circ} \mathrm{C}\right)\right.\end{array}$}} & \multirow[b]{2}{*}{$\begin{array}{l}\text { Half-life } \\
\text { in soil } \\
\text { (days) }\end{array}$} & \multirow{2}{*}{$\begin{array}{l}\text { Chemical } \\
\text { class }\end{array}$} & \multirow[t]{2}{*}{ Molecular structure } \\
\hline & $\begin{array}{c}\text { Rate } \\
\left(\mathrm{kg} \mathrm{a.i.} \mathrm{ha}^{-1}\right)\end{array}$ & $\begin{array}{l}\text { Concentra- } \\
\text { tion } \\
\left(\mathrm{mg} \mathrm{L}^{-1}\right)\end{array}$ & $\begin{array}{l}\text { pressure } \\
(\mathrm{mPa} \text { at } \\
\left.20^{\circ} \mathrm{C}\right)\end{array}$ & & & & & & \\
\hline
\end{tabular}

\begin{tabular}{|c|c|c|c|c|c|c|c|c|}
\hline Ametryn & 4.0 & 16,000 & 0.37 & 316 & 200 & 10.1 & 37 & Triazine \\
\hline Diuron & 3.2 & 12,800 & 0.00115 & 813 & 35.6 & NA & 76 & Phenylurea \\
\hline Hexazinone & 0.4 & 1,600 & 0.03 & 54 & 33000 & 2.2 & 105 & Triazine \\
\hline Sulfentrazone & 0.6 & 2,400 & 0.00013 & 43 & 780 & 6.6 & 541 & Triazole \\
\hline
\end{tabular}


decanted into a round bottom flask. Two further extractions were performed, each with $100 \mathrm{~mL}$ of dichloromethane, and the dichloromethane fractions were combined. The dichloromethane was removed by evaporating the combined extracts to complete dryness in a rotary evaporator. The residue was dissolved in $5 \mathrm{~mL}$ of acetonitrile, and passed through a $0.45 \mu \mathrm{m}$ regenerated cellulose syringe filter.

Identification and quantification of the herbicide residues in the acetonitrile solutions were performed with a highperformance liquid chromatograph (HPLC) equipped with a diode array detector (DAD) (Varian Model 920-LC). Chromatographic separation was on a Pursuit XRs C-18 reverse phase column $(25 \mathrm{~cm} \times 4.6 \mathrm{~mm} \times 5 \mu \mathrm{m})$ with a Pursuit XRs C-18 pre-column ( $2.5 \mathrm{~cm} \times 4.6 \mathrm{~mm} \times 5 \mu \mathrm{m})$, both maintained at a temperature of $40{ }^{\circ} \mathrm{C}$. The solvent program was $40 \%$ acetonitrile / $60 \%$ ultrapure water $+\mathrm{H}_{3} \mathrm{PO}_{4}(0.1 \% \mathrm{v} / \mathrm{v})$ for 12 minutes, then $100 \%$ acetonitrile for 5 minutes, followed by $40 \%$ acetonitrile / $60 \%$ ultrapure water $+\mathrm{H}_{3} \mathrm{PO}_{4}(0.1 \% \mathrm{v} / \mathrm{v})$ for
8 minutes. The solvent flow was $1 \mathrm{~mL} \mathrm{~min}^{-1}$, and the injection volume was $20 \mu \mathrm{L}$. Under these conditions, the retention times for ametryn, diuron, hexazinone, and sulfentrazone were $5.25,13.24,6.80$, and 12.65 minutes, respectively. Absorbances at the following wavelengths were recorded to quantify the pesticides in the samples: $221 \mathrm{~nm}$ for ametryn, $250 \mathrm{~nm}$ for diuron, $246 \mathrm{~nm}$ for hexazinone, and $227 \mathrm{~nm}$ for sulfentrazone. Validation of the analytical method established that the quantification limits in water for ametryn, hexazinone, and sulfentrazone were $10 \mu \mathrm{g} \mathrm{L}^{-1}$, while for diuron the limit was $5 \mu \mathrm{g} \mathrm{L}^{-1}$. The average recovery of the method was $95.3 \%$ for ametryn, $99.3 \%$ for diuron, $93.3 \%$ for hexazinone, and $106 \%$ for sulfentrazone. The coefficients of variation for precision were below $20 \%$ for all herbicides. The criteria used for method validation (i.e. recoveries between 70 and $120 \%$ and coefficients of variation for precision below 20\%) was based on INMETRO (2018). Chromatograms of the standard solution at $10 \mu \mathrm{g} \mathrm{L}^{-1}$ for all herbicides and the comparison with one sample are shown in Figure 2.
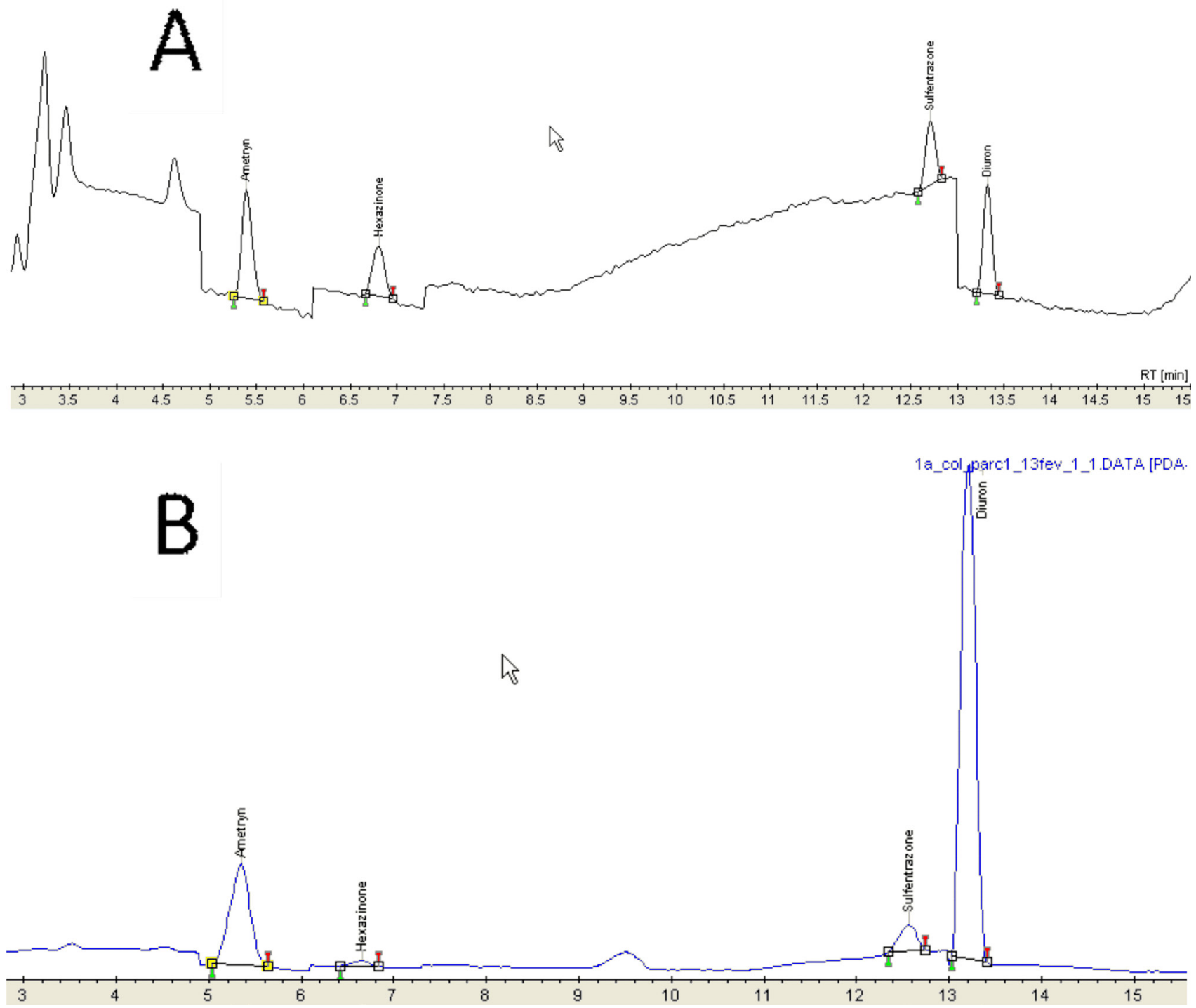

Figure 2. Chromatograms of the standard solution at $10 \mu \mathrm{g} \mathrm{L}-1$ for all herbicides (A) and one sample collected on 10 Dec. 2015 (B). 


\section{Study chronogram}

The detailed chronograms of the two runoff experiments are presented in Table 2. The duration of the first experiment (Experiment A), in which sugarcane straw was not applied to the soil, from application of the herbicides on 09 December, 2015 to the last collection of runoff water on 05 February, 2016, was 59 days, and included six collections of runoff water. During the second experiment (Experiment B), in which varying amounts of greenhouse-dried sugarcane straw were distributed over the soil before the application of the herbicides on 07 December, 2016, seven collections of runoff water were performed.

\section{RESULTS AND DISCUSSION}

\section{Meteorological conditions and water balance}

The daily average air temperature ranged from 19 to $31{ }^{\circ} \mathrm{C}$ for Experiment A, and from 23 to $29{ }^{\circ} \mathrm{C}$ for Experiment B. The accumulated rainfall during Experiment A (09 December, 2015 to 05 February, 2016; 59 days) was $580.2 \mathrm{~mm}$, while for Experiment B (07 December, 2016 to 10 February, 2017; 66 days) the total rainfall was $378.8 \mathrm{~mm}$ (Figure 3). These values can be compared against the historical records of rainfall at Embrapa Agropecuária Oeste, which cover the period from 1979 to 2014 (35 years). For the period 09 December to 05 February of the following year, the historical average accumulated rainfall is $299.9 \mathrm{~mm}$ with a standard deviation of $93.3 \mathrm{~mm}$, and the $580.2 \mathrm{~mm}$ of total rainfall registered between 09 December, 2015 and 05 February, 2016 was greater than the highest value previously recorded for this period. The conditions under which Experiment A was run may accordingly be considered as "extreme," and the exceptionally heavy rainfall will have implications for the interpretation of the surface runoff results obtained. The historical average accumulated rainfall for the period from 07 December to 10 February of the following year is $341.5 \mathrm{~mm}$ with a standard deviation of $103.3 \mathrm{~mm}$. The total rainfall of

Table 2. Chronogram of the two runoff experiments. Experiment A was performed without the application of sugarcane straw to the soil.

\begin{tabular}{lcc}
\hline \multirow{2}{*}{ Activity } & \multicolumn{2}{c}{ Experiments } \\
\cline { 2 - 3 } & $\mathrm{A}$ & $\mathrm{B}$ \\
\hline Straw collection & - & $01 / \mathrm{Nov} / 2016$ \\
Straw application & - & $17 / \mathrm{Nov} / 2016$ \\
Herbicide application & $09 / \mathrm{Dec} / 2015$ & $07 / \mathrm{Dec} / 2016$ \\
Runoff water collection & 10/Dec/2015(1)* & $12 / \mathrm{Dec} / 2016(5)^{*}$ \\
& 14/Dec/2015(5) & $14 / \mathrm{Dec} / 2016(7)$ \\
& 21/Dec/2015(12) & $28 / \mathrm{Dec} / 2016(21)$ \\
& $04 / \mathrm{Jan} / 2016(26)$ & $05 / \mathrm{Jan} / 2017(29)$ \\
& 15/Jan/2016(37) & $27 / \mathrm{Jan} / 2017(51)$ \\
& $05 / \mathrm{Feb} / 2016(58)$ & $02 / \mathrm{Feb} / 2017(57)$ \\
& & $10 / \mathrm{Feb} / 2017(65)$ \\
\hline
\end{tabular}

"Numbers within parenthesis are "Days after herbicide application".
$378.8 \mathrm{~mm}$ registered between 07 December, 2016 and 10 February, 2017 was thus "typical," and corresponded to $111 \%$ of the historical average for this period.

The estimated accumulated water balance was obtained by subtracting the accumulated reference crop evapotranspiration, $\Sigma E T_{o}$, from the accumulated rainfall. During Experiment A, the accumulated rainfall always exceeded the accumulated reference crop evapotranspiration, indicating a positive estimated water balance (water excess) throughout the experimental period (Figure 3), which should have led to greater surface runoff. For Experiment B, the accumulated rainfall was much closer to the accumulated reference crop evapotranspiration, and there were some days where the accumulated rainfall was less than the accumulated reference crop evapotranspiration, producing a negative estimated water balance (Figure 3).

The daily rainfall for the period from 09 December, 2015 to 05 February, 2016 (Experiment A) ranged from 0.2 to $90.6 \mathrm{~mm}$ (Figure 3). The highest observed daily rainfall, $90.6 \mathrm{~mm}$, occurred during the 24-hour period following the application of the herbicides to the experimental plots. For the period from 07 December, 2016 to 10 February, 2017 (Experiment B), the daily rainfall ranged from 0.1 to $65.4 \mathrm{~mm}$, with $40.9 \mathrm{~mm}$ falling two days after the application of the herbicides to the experimental plots. Rainfall intensity is a determining factor in the formation of surface runoff.
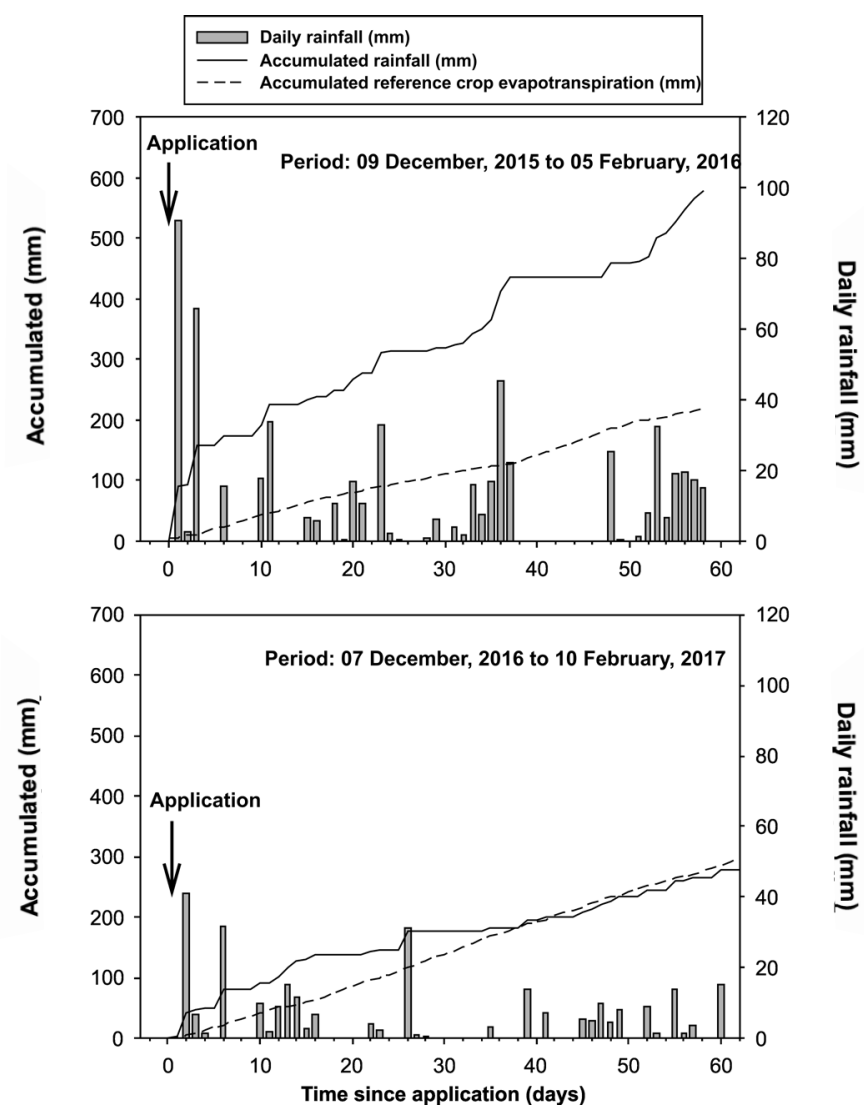

Figure 3. Daily rainfall, together with accumulated rainfall, and reference crop evapotranspiration, for Experiment A (December 2015 to February 2016) and Experiment B (December 2016 to February 2017). 
The higher the rainfall intensity, the faster the soil saturates, and the greater the process of surface runoff is promoted. In confirmation of this link between rainfall intensity and the promotion of surface runoff, Defersha \& Melesse (2012) have observed that the average surface runoff rate increases with the rainfall intensity.

Both the duration and intensity of rainfall events are important factors influencing the amount of herbicides transported from soils by surface runoff (Lefrancq et al., 2017; Müller et al., 2004). The meteorological records were inspected to determine the rainfall intensity frequency distributions for the observational periods of the two experiments. During Experiment A, 98\% of the rainfall events occurred with intensities between 0 and $15 \mathrm{~mm} \mathrm{~h}^{-1}$ and $2 \%$ between 20 and $25 \mathrm{~mm} \mathrm{~h}^{-1}$. For Experiment B, 98\% of the rainfall events occurred with intensities between 0 and $20 \mathrm{~mm} \mathrm{~h}^{-1}, 1 \%$ with intensities between 20 and $30 \mathrm{~mm} \mathrm{~h}^{-1}$, and $1 \%$ with intensities between 30 and $40 \mathrm{~mm} \mathrm{~h}^{-1}$.

\section{Volume of surface runoff water}

For experiment A, in which the soil of the plots was not covered with straw, the average accumulated volume of runoff water for a single plot was $3878 \mathrm{~L}$, with a standard error $(9$ replicates) of $199 \mathrm{~L}$. Expressed as rainfall on the plots, this volume corresponded to $97( \pm 5) \mathrm{mm}$, or $16.7( \pm 0.9) \%$ of the accumulated rainfall. In Experiment B, where the 9 plots were divided into 3 groups, with each group having a different level of soil coverage by straw, there were differences between the groups in the volume of water collected (Figures 4A and 4B). Upon comparing the runoff volume data obtained from Experiment A with the 0\% straw plots of Experiment B, it is apparent that a much greater volume of runoff water was collected during Experiment A, 3878 L, compared to $818 \mathrm{~L}$ during Experiment B (Figure 4A). This is only in part due to the higher total rainfall of Experiment A ( $580.2 \mathrm{~mm}$ compared to $378.8 \mathrm{~mm}$ ), as when the collected volume of runoff water is expressed as a fraction of the accumulated rainfall the difference between Experiment A and the 0\% straw plots of Experiment B remains large (16.7\% compared to 5.4\%; Figure 4B). The intensity of the rainfall also seems unable to explain the much higher runoff observed in Experiment A, since in both experiments approximately $98 \%$ of the rainfall events had an intensity of less than $20 \mathrm{~mm} \mathrm{~h}^{-1}$.

Another factor of significant influence in the generation of surface runoff is the moisture content of the soil (Zhang et al., 1997). Throughout Experiment A, the accumulated water balance was large and positive (Figure 3), conditions under which the soil moisture content is expected to be high. During Experiment B, the estimated accumulated water balance was much smaller and sometimes negative, due to the reference crop evapotranspiration exceeding the rainfall, leading to a lower soil moisture content than for Experiment A. Higher levels of water in the soil decrease the start time for surface runoff and, consequently, promote higher runoff volumes (Masters et al., 2013). In addition, the higher the water content
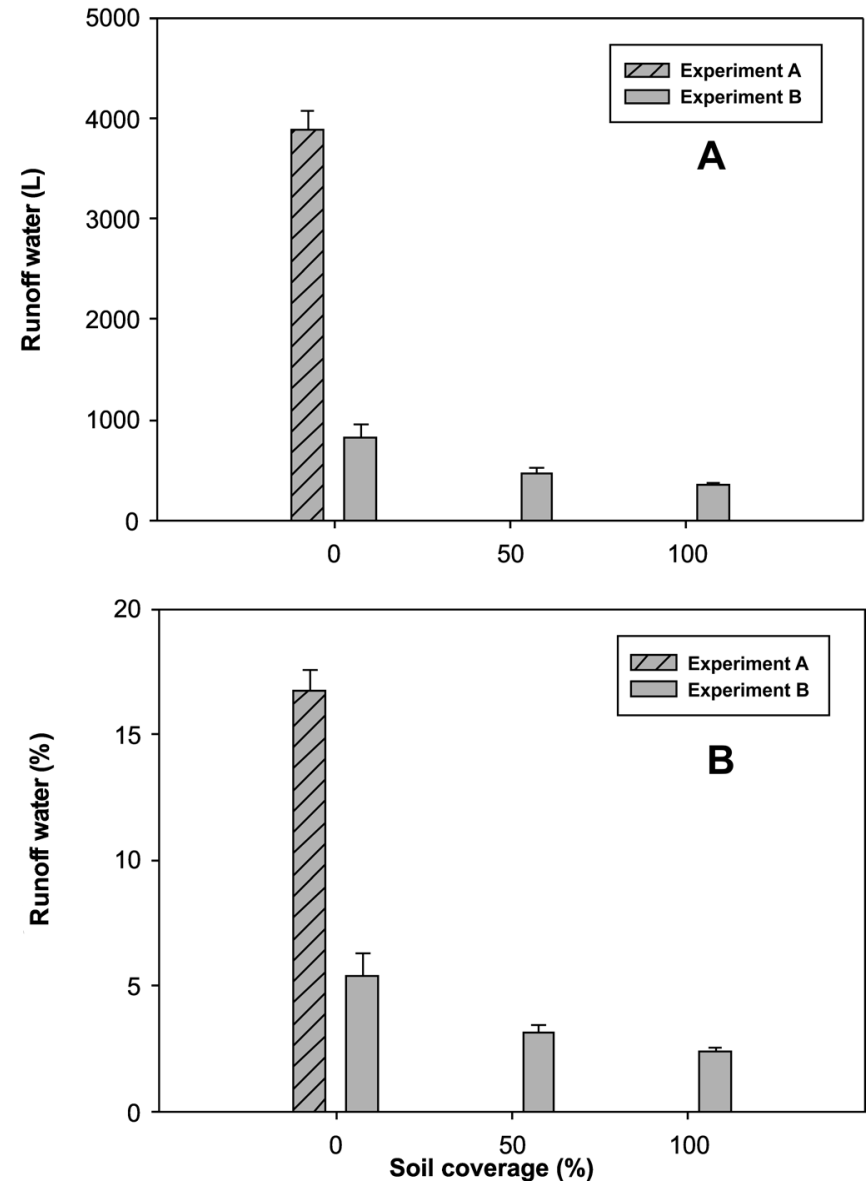

Figure 4. Comparison of the quantities of runoff water from an experimental plot, between Experiment A and Experiment B, and for different levels of coverage of the soil with straw (Experiment B). The results are presented as the volume of water collected (A), and as the fraction of the accumulated rainfall collected as runoff water (B). The column heights are the averages, the error bars are \pm 1 standard error.

already present in the soil, the smaller the ability of the soil to absorb more water from rainfall, so that a greater proportion of the incident rainfall will appear as runoff (Zhao et al., 2015).

The amount of runoff water collected from the plots was influenced by the presence of straw on the soil (Figure 4; Experiment B). Increasing the coverage of the soil with sugarcane straw produced a reduction in the volume of surface runoff water. The plots with 50 and $100 \%$ coverage of the soil by straw yielded 58 and $44 \%$, respectively, of the volume of runoff water collected from the plots without straw $(0 \%$ soil coverage). In similar runoff studies with varying levels of straw coverage, Vaz (2016) and Silva et al. (2012) observed that $50 \%$ coverage of the soil with sugarcane straw, corresponding to $7 \mathrm{Mg} \mathrm{ha}^{-1}$, was sufficient to reduce the surface runoff, and that increasing the coverage beyond $50 \%$ produced no further significant reduction in the volume of surface runoff.

Vegetation coverage plays an important role in the control of water loss from fields. The roughness provided by plant residues left on the soil surface produces barriers that help to reduce surface runoff (Garbiate et al. 2011). Almeida et al. (2016), analyzing accumulated water loss data from bare 
soil, soil planted with soybean, and established pasture, found that the absence of vegetation reduced the rate of water infiltration and increased the superficial runoff. These effects were attributed to the surface of the bare soil becoming sealed by the direct impact of raindrops.

Leaving straw on the field, which has been made possible by the introduction of mechanized sugarcane harvesting, has benefits for the quality of the soil. The results obtained from Experiment B demonstrate how covering the soil with straw reduces surface runoff. Other reported agricultural benefits are through ecosystem services including nutrient recycling, soil biodiversity, and carbon accumulation. However, sugarcane straw is also a feedstock for bioenergy production in the latest generation of ethanol production plants. Given these two competing uses, the study of the minimum straw levels required to provide the previously mentioned agronomic benefits has gained importance, with a recent review recommending the retention of at least $7 \mathrm{Mg} \mathrm{ha}^{-1}$ of dry straw on the soil surface (Carvalho et al. 2016).

\section{Herbicide losses}

The concentrations of ametryn, diuron, hexazinone, and sulfentrazone found in the analyzed aliquots of runoff water were used to calculate the mass of each pesticide removed from a plot in the interval between two consecutive runoff water collection days. Division of these masses by the mass of pesticide applied to a plot (16.0 $\mathrm{g}$ of ametryn, $12.8 \mathrm{~g}$ of diuron, $1.6 \mathrm{~g}$ of hexazinone, and $2.4 \mathrm{~g}$ of sulfentrazone) gave the fraction of the applied dose removed from the plot by transport in the surface runoff. Cumulative totals were also calculated.

In Experiment A, the highest concentrations of ametryn, diuron, and sulfentrazone in the surface runoff water were found in the aliquots of water collected on day 1 of the experiment, one day after the application and just after the first rainfall event. These highest concentrations (mean \pm 1 standard error over the nine experimental plots) were $615( \pm 43) \mu \mathrm{g} \mathrm{L}^{-1}$ for ametryn, $637( \pm 50) \mu \mathrm{g} \mathrm{L}-1$ for diuron, and $24( \pm 5) \mu \mathrm{g} \mathrm{L}^{-1}$ for sulfentrazone. The lowest quantified concentrations were $18( \pm 0.9) \mu \mathrm{g} \mathrm{L}^{-1}$ for ametryn (water collected at the end of day 12), $6( \pm 0.6) \mu \mathrm{g} \mathrm{L}{ }^{1}$ for diuron (water collected at the end of day 58), and $9( \pm 3) \mu \mathrm{g} \mathrm{L}^{-1}$ for sulfentrazone (water collected at the end of day 5). No hexazinone was detected in any of the collected samples of surface runoff water.

The results obtained from Experiment A (no straw on any of the nine plots), expressed as a fraction of the applied dose, are presented in Figure 5. The cumulative totals of the fractions of applied pesticide transported from the plots in surface runoff water were $6.0 \%$ for ametryn, $8.6 \%$ for diuron, and $2.4 \%$ for sulfentrazone. The cumulative losses for ametryn, diuron, and sulfentrazone were tested for possible correlations with the physicochemical properties listed in Table 1. There was a strong and statistically significant negative correlation of the loss with the solubility of the pesticide in water (correlation coefficient, $r=-0.96 ; p<0.05$ ), and a strong and statistically significant positive correlation with the adsorption coefficient of the pesticide normalized to the organic carbon content of the soil, $K_{o c}(r=0.98 ; p<0.05)$. These correlations demonstrate the importance of the degree of infiltration into the soil in determining losses from bare soil by transport in surface runoff water. Molecules with lower solubility and higher $K_{o c}$ infiltrate less into the soil, and are thus exposed for a longer time on the soil surface for the transport by surface runoff (Gomides et al. 2008; Ulrich et al. 2013). The transport of pesticides from fields through surface runoff is a complex process, which is influenced not only by the physicochemical characteristics of the molecule, but also by various soil and climatic factors, including the hydrological characteristics of the soil, the coverage of the soil by vegetation, and the intensity of the rainfall (Müller et al. 2004). The observation from Experiment A of the present study that no hexazinone was transported in the runoff water differs from the results of most other studies into the mobility of this pesticide, which have consistently reported the presence of hexazinone in runoff water (Prichard et al. 2005; Masters et al. 2013). A possible explanation of the present observations is that the hexazinone, which is highly soluble in water, after application onto the bare soil, was transported into the soil with the infiltration water during the early stages of the first rainfall event. There was heavy rain $(90.6 \mathrm{~mm})$ during the 24-hour period following the application of the herbicides (Figure 3); however, the rainfall was distributed throughout the day rather than occurring in a short, high-intensity event. These specific conditions, bare soil and continuous moderate-intensity rain, presumably allowed the hexazinone to infiltrate completely into the soil, before surface runoff commenced, rendering the hexazinone unavailable for transportation in the runoff water.

As previously noted, for Experiment A, a large quantity of rain $(90.6 \mathrm{~mm})$ fell during the 24-hour period following the application of the herbicides to the plots, and this rain was responsible for 86,82 , and $51 \%$ of the total losses of ametryn, diuron, and sulfentrazone, respectively (Figure 6). When an extreme rain event occurs, as happened at the start of Experiment A, it will often account for the major fraction of the contaminants, in the present case herbicides, transported by surface runoff. Shipitalo \& Owens (2006) conducted a nine-year study of the removal of herbicides by surface runoff, and found that during this entire period just five surface runoff events were responsible for 60 to $99 \%$ of the total observed herbicide losses across seven different sites. Climate change models predict that extreme precipitation events will become more frequent (Marengo et al. 2009), so that more cases of the sudden removal of substantial quantities of pesticides in runoff water should be anticipated.

The length of time between the application of an herbicide and the occurrence of the first post-application rainfall can influence significantly the losses of the herbicide. Several authors have demonstrated an inverse relationship between the elapsed time from pesticide application to first rainfall and the quantity of herbicide lost in surface runoff water (Masters et al. 2013; Silburn et al. 2013). In Experiment A of the present study, the occurrence of sustained heavy rain soon after the 

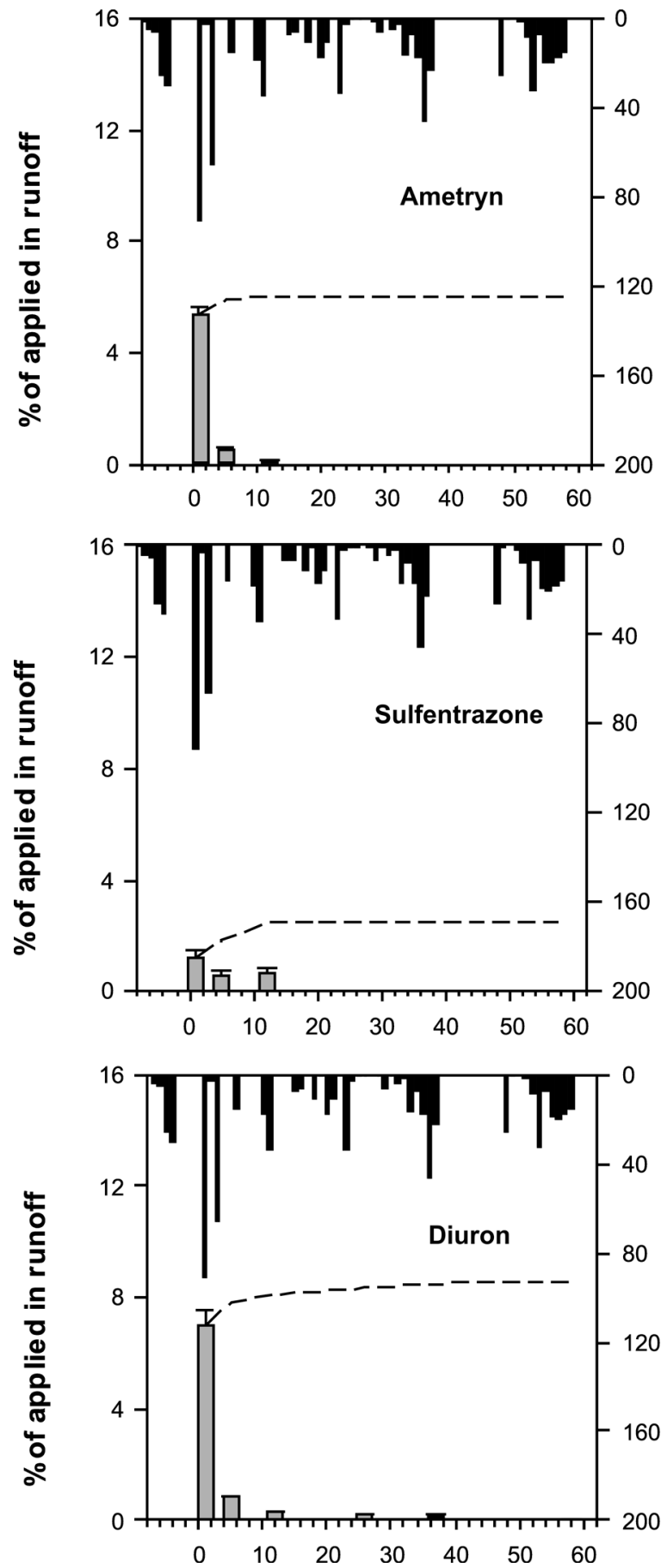

Figure 5. Ametryn (A), sulfentrazone (B), and diuron (C) residues present in the runoff water for Experiment A (no straw) as a function of time after the application of the herbicides to the plots. The results are presented as the quantity found in the runoff water collected at the end of days 1, 5, 12, 26, 37 , and 58 (vertical columns), and as the cumulative sum (dashed line). The column heights and points are averages over the nine replicate plots, error bars are \pm 1 standard error. In all cases the results are expressed as a fraction of the applied dose. For comparison, the daily rainfall totals are also shown on the same time scale.

application of the herbicides provided a scenario for substantial herbicide losses by surface runoff. The losses observed for ametryn, diuron, and sulfentrazone were quite high compared to other studies of rain-promoted surface transport of these molecules (Davis et al. 2013; Masters et al. 2013).
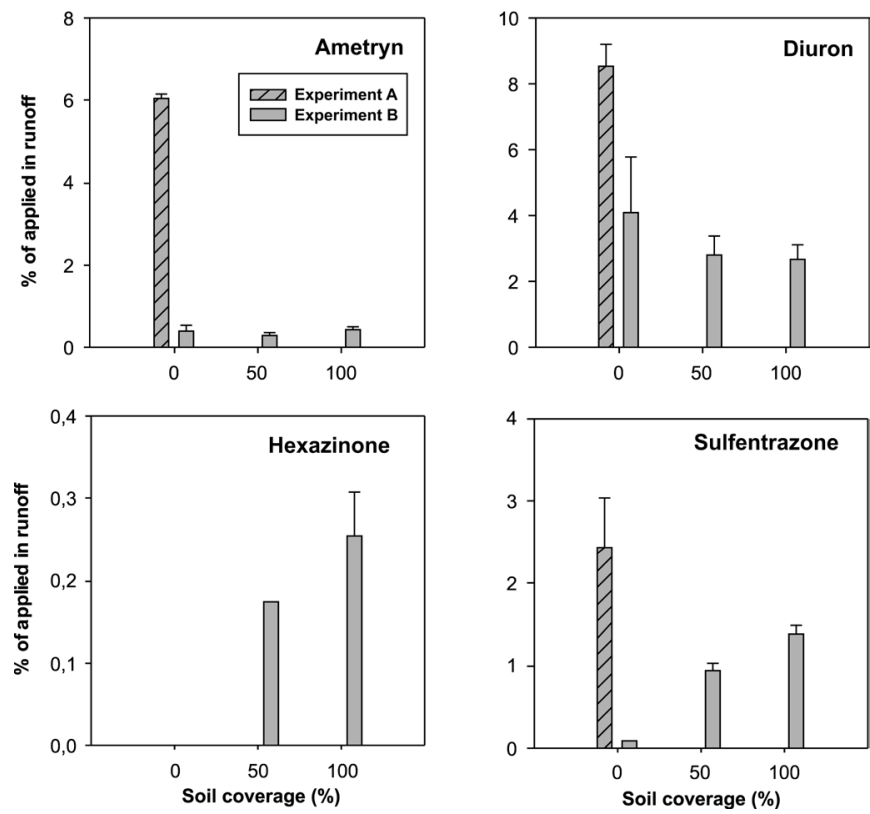

Figure 6. Cumulative totals of the ametryn, diuron, hexazinone, and sulfentrazone residues present in the runoff water for Experiment A (no straw) and Experiment B (0, 50\% and 100\% coverage) as a function of the coverage of the soil by straw. The column heights are averages over the replicate plots (nine for Experiment A, three for each coverage of Experiment B), error bars are \pm 1 standard error. In all cases the results are expressed as a fraction of the applied dose. Note different scales for $y$-axis

In Experiment $\mathrm{B}$, the highest concentrations (mean \pm 1 standard error over the three experimental plots for each treatment) of the pesticides in the surface runoff water were $341( \pm 34) \mu \mathrm{g} \mathrm{L}{ }^{1}$ for ametryn (water collected at the end of day 7 from the $100 \%$ straw plot), $1648( \pm 347) \mu \mathrm{g} \mathrm{L}^{-1}$ for diuron (water collected at the end of day 7 from the $100 \%$ straw plot), $22( \pm 83) \mu \mathrm{g} \mathrm{L}^{-1}$ for hexazinone (water collected at the end of day 7 from the $100 \%$ straw plot), and $167( \pm 14) \mu \mathrm{g} \mathrm{L} \mathrm{L}^{-1}$ for sulfentrazone (water collected at the end of day 7 from the $100 \%$ straw plot). The lowest quantified concentrations were $12( \pm 2) \mu \mathrm{g} \mathrm{L}^{-1}$ for ametryn (water collected at the end of day 29 from the $50 \%$ straw plot), $14( \pm 2) \mu \mathrm{g} \mathrm{L}^{-1}$ for diuron (water collected at the end of day 65 from the $50 \%$ straw plot), $12 \mu \mathrm{g} \mathrm{L}^{-1}$ for hexazinone (water collected at the end of day 5 from the $50 \%$ straw plot), and $27( \pm 4) \mu \mathrm{g} \mathrm{L}^{-1}$ for sulfentrazone (water collected at the end of day 7 from the $50 \%$ straw plot). No hexazinone was detected in any of the samples of runoff water collected from the plots without straw. In both Experiment A and Experiment B, the highest concentrations for ametryn and diuron in the samples of runoff water were greater than for hexazinone and sulfentrazone, as might be anticipated from the relative applied doses of the herbicides: $16.0 \mathrm{~g}$ of ametryn and $12.8 \mathrm{~g}$ of diuron per plot compared to $1.6 \mathrm{~g}$ of hexazinone and $2.4 \mathrm{~g}$ of sulfentrazone.

The total quantities of ametryn, diuron, hexazinone, and sulfentrazone collected in the surface runoff water, expressed as a fraction of the applied dose, during the 58-day duration of Experiment A and the 65-day duration of experiment B, as a function of the coverage of the soil by sugarcane straw, 
are presented in Figure 6. With no straw on the ground, no hexazinone was detected in the runoff water in either Experiment A or Experiment B. Runoff water removed 0.2 and $0.3 \%$ of the applied dose of hexazinone for the plots with 50 and $100 \%$ coverage of the soil by straw, respectively. Hexazinone is highly soluble in water, $33 \mathrm{~g} \mathrm{~L}^{-1}$, and from its low $K_{o c}, 54 \mathrm{~mL} \mathrm{~g}^{-1}$ (Table 1), it is predicted to be weakly retained in soil. From these physicochemical properties, it might be expected that substantial quantities of hexazinone would have been found in the surface runoff water. However, it seems that under the conditions of both Experiment A and Experiment B, with no straw on the ground, the applied hexazinone was transported into the soil, from where it did not enter the surface runoff water produced by rainfall. The presence of hexazinone residues in the runoff water when the soil was covered with straw suggests that during application some of the hexazinone was retained in the straw, from where a fraction could be released into runoff water by subsequent rainfall. Increasing the amount of soil straw on the soil led to an increase in the quantity of applied hexazinone appearing in the runoff water. Toniêto et al. (2016) have reported the physical trapping of hexazinone in straw. Vaz (2016) examined the removal of hexazinone from plots with three levels of sugarcane straw coverage $\left(0,7\right.$, and $\left.14 \mathrm{Mg} \mathrm{ha}^{-1}\right)$ under intense simulated rain $\left(80 \mathrm{~mm} \mathrm{~h}^{-1}\right.$ for 90 minutes), and found no significant variations in the losses of hexazinone.

For sulfentrazone, the total losses in surface runoff water over the 66 days of Experiment B were 0.09, 0.94, and $1.4 \%$ of the applied dose for the treatments with 0,50 , and $100 \%$ coverage of the soil with straw, respectively (Figure 6). In common with the results obtained for hexazinone, the fraction of the applied sulfentrazone carried from the plots by surface runoff water increased with the coverage of the soil by straw. An examination of the physicochemical properties of sulfentrazone (Table 1) reveals that sulfentrazone is moderately soluble in water $\left(780 \mathrm{mg} \mathrm{L}^{-1}\right)$ and will be retained only weakly in the soil $\left(K_{o c}=43 \mathrm{~mL} \mathrm{~g}^{-1}\right)$. As for hexazinone, it is proposed that some of the applied sulfentrazone is retained in the straw, from where it may subsequently be dislodged by rainfall to emerge in the runoff water (Dang et al. 2016). This suggestion is supported by the results from a number of other studies of sulfentrazone sprayed onto sugarcane straw. An examination of the herbicidal effects of sulfentrazone sprayed onto bare soil and soil covered with $10 \mathrm{Mg} \mathrm{ha}^{-1}$ of straw led Correia et al. (2013) to argue that when sprayed onto straw the sulfentrazone was retained on the straw until there was rainfall, and that $20 \mathrm{~mm}$ of rainfall were sufficient to transport the sulfentrazone from the straw to the soil. Simoni et al. (2006) found that the herbicidal effects of sulfentrazone were attenuated by the presence of $20 \mathrm{Mg} \mathrm{ha}^{-1}$ of straw on the soil, and that full efficacy was recovered by the application of $20 \mathrm{~mm}$ of simulated rainfall 1 day or 7 days after the sulfentrazone was sprayed on the plots. Further, $10 \mathrm{Mg} \mathrm{ha}^{-1}$ of straw did not reduce the effects of the applied sulfentrazone, and with $20 \mathrm{Mg} \mathrm{ha}^{-1}$ of straw, $10 \mathrm{~mm}$ of simulated rain was not sufficient to restore the efficacy of the sulfentrazone. More recently, Carbonari et al. (2016) observed that, from straw layers equivalent to $5,10,15$, and $20 \mathrm{Mg} \mathrm{ha}^{-1}$, the initial $20 \mathrm{~mm}$ of simulated rainfall released the maximum mass of sulfentrazone, and that the mass of sulfentrazone recovered was dependent on the mass of straw. Returning to the results of Experiment B, quantifiable concentrations of sulfentrazone were only found in the runoff water collected on day 5 (first collection), and day 7 (runoff water amassed after the first collection), from the plots with $50 \%\left(9 \mathrm{Mg} \mathrm{ha}^{-1}\right)$ and $100 \%$ $\left(18 \mathrm{Mg} \mathrm{ha}^{-1}\right)$ straw coverage. The accumulated rainfall between the application of the herbicides and the first collection of runoff water (day 5) was $49 \mathrm{~mm}$, and between the first and second collections (day 5 to day 7) was $31 \mathrm{~mm}$. With $20 \mathrm{~mm}$ of rainfall as the threshold value to liberate sulfentrazone from sugarcane straw at up to $20 \mathrm{Mg} \mathrm{ha}^{-1}$, the $49 \mathrm{~mm}$ of rain that fell prior to the water collection of day 5 should have been sufficient to leach the sulfentrazone from the straw, from where it could either have appeared in the runoff resulting from the same rain or been transported into the soil. Once in the soil, subsequent rain could have lifted the sulfentrazone into the surface water so that it appeared in the collected runoff water.

The total amounts of diuron transported in surface runoff water for Experiment B were 4.1, 2.8, and 2.7\% of the applied dose for the treatments with 0,50 and $100 \%$ straw coverage, respectively (Figure 6). In contrast to hexazinone and sulfentrazone, the largest amount of diuron was removed from plots with no straw, and the presence of straw at 50 or $100 \%$ coverage reduced the diuron surface runoff losses by a factor of 1.5 . The behavior of diuron, which is only slightly soluble in water $\left(36.6 \mathrm{mg} \mathrm{L}^{-1}\right)$, is in accord with the common observation that soil coverage by plants and plant residues reduces the surface transport in water of pesticide residues (Alletto et al. 2010; Rossi et al. 2013; Vaz, 2016). For the specific case of diuron, Vaz (2016) observed that $7 \mathrm{Mg} \mathrm{ha}^{-1}$ of sugarcane straw were sufficient to decrease diuron losses in surface runoff, due to a single intense simulated-rainfall event ( $80 \mathrm{~mm} \mathrm{~h}^{-1}$ for 90 minutes), from 57 (no straw) to $20 \mathrm{~g}$ ha ${ }^{1}$, which corresponded to 4.0 and $1.4 \%$ of the applied dose, respectively. Doubling the straw coverage to $14 \mathrm{Mg} \mathrm{ha}^{-1}$ produced no further decrease in the losses of diuron.

The total amounts of ametryn transported in surface runoff water for Experiment B were 0.40, 0.30, and 0.44\% of the applied dose for the 0,50 , and $100 \%$ soil coverage by straw treatments, respectively (Figure 6). Therefore placing sugarcane straw on the surface of the soil prior to the application of ametryn has no effect on the transport of ametryn by surface water. Ametryn has a solubility in water $\left(200 \mathrm{mg} \mathrm{L}^{-1}\right)$ that is intermediate between the solubilities of sulfentrazone, for which straw coverage significantly increased the fraction of the applied dose found in runoff water, and diuron, where the runoff loses were insensitive to the presence of straw on the soil. When there is straw on the soil, much of the applied dose will be initially retained in the straw. The behavior of these straw-retained molecules in response to the first rainfall will depend on their solubility in water. Less rain will be required to liberate the more soluble molecules (hexazinone and sulfentrazone) from the straw, so that they can enter the 
runoff water or be transported into the soil. Hexazinone and sulfentrazone have relatively weak sorption onto the soil (low values of $K_{o c}$, Table 1), so that some losses from the soil into surface runoff water are probable. Ametryn is less soluble and sorbs more strongly to soil. It is possible that the ametryn that appeared in the runoff water was derived from ametryn still attached to the straw after the first rainfall events, and that with no straw the ametryn was from direct washoff of ametryn on the surface of the soil. A similar argument can be proposed for diuron, with the much lower solubility of diuron leading to the retention of a greater proportion of this molecule in the straw or on the surface of the soil, and hence greater losses in surface runoff triggered by rainfall events. The dynamics of the transport of pesticides in surface runoff, with and without the presence of straw, are complex and are likely to involve factors (Masters et al. 2013) that are beyond the scope of the present discussion and the data available from the present study.

\section{CONCLUSIONS}

The results obtained in the present study have shown several effects from leaving sugarcane straw on the soil after the mechanized harvesting of the canes. The volume of surface runoff water is decreased. Reasons for this beneficial decrease include maintenance of the water infiltration capacity of the soil, increased roughness on the surface of the soil, and a reduction in the superficial sealing of the soil caused by the direct impact of raindrops on the soil. The losses of herbicides in surface runoff water depend on the physicochemical characteristics of the molecules. For the more water-soluble herbicides included in the present study, hexazinone and sulfentrazone, the presence of sugarcane straw on the soil increased the total amount of herbicide collected in the runoff water. It is proposed that herbicide residues retained in the straw are released by rainfall to then appear in surface runoff water. For the less soluble ametryn and diuron, the total amounts collected in runoff water appeared to be insensitive to the degree of coverage of the soil with sugarcane straw, with the losses of diuron, the least soluble molecule, considerably exceeding those of ametryn.

\section{ACKNOWLEDGMENTS}

The authors would like to thank Embrapa for supporting this work. Laboratory technician Paulo Henrique Vitro of Embrapa Agropecuária Oeste is thanked for his help in the laboratory analyses, agricultural technicians Mauro Alves Júnior and Anderson Bonin, also of Embrapa Agropecuária Oeste, are thanked for their help in the collection of samples from the experimental plots.

\section{REFERENCES}

ALLEN, R.G., PEREIRA, L.S., RAES, D. \& SMITH, M. 1998. Crop evapotranspiration: Guidelines for computing crop water requirements. Irrigation and Drainage, 56-300p. http://www.fao. org/3/x0490e/x0490e00.htm

Alletto, L., COQUET, Y., BENOIT, P., HEDDAD, J.D. \& BARRIUSO, E. 2010. Tillage management effects on pesticide fate in soils. A review. Agron. Sustain. Dev., 30: 367-400. http:// dx.doi.org/10.1051/agro/2009018

ALMEIDA, W.S., CARVALHO, D.F., PANACHUKI, E., VALIM, W,C., RODRIGUES, A.S. \& VARELLA, C.A.A. 2016. Erosão hídrica em diferentes sistemas de cultivo e níveis de cobertura do solo. Pesqui. Agropecu. Bras., 51(9): 1110-1119. http://dx.doi. org/10.1590/s0100-204x2016000900010

ANACHE, J.A.A., WENDLAND, E.C., OLIVEIRA, P.T.S., FLANAGAN, D.C. \& NEARING, M.A. 2017. Runoff and soil erosion plot-scale studies under natural rainfall: A meta-analysis of the Brazilian experience. Catena, 152: 29-39. http://dx.doi. org/10.1016/j.catena.2017.01.003

ARALDI, R., VELINI, E.D., GOMES, G.L.G.C., TROPALDI, L., SILVA, I.P.F. \& CARBONARI, C.A. 2015. Performance of herbicides in sugarcane straw. Cienc. Rural, 45(12): 2106-2112. http://dx.doi.org/10.1590/0103-8478cr20141244

BORDONAL, R.O., MENANDRO, L.M.S., BARBOSA, L.C., LAL, R., MILORI, D.M.B.P., KOLLN, O.T., FRANCO, H.C.J. \& CARVALHO, J.L.N. 2018. Sugarcane yield and soil carbon response to straw removal in south-central Brazil. Geoderma, 328: 79-90. http://dx.doi.org/10.1016/j.geoderma.2018.05.003

CARBONARI, C.A., GOMES, G.L.G.C., TRINDADE, M.L.B., SILVA, J.R.M. \& VELINI, E.D. 2016. Dynamics of sulfentrazone applied to sugarcane crop residues. Weed Sci., 64(1): 201-206. http://dx.doi.org/10.1614/WS-D-14-00171.1

CARBONARI, C.A., VELINI, E.D., CORREA, M.R., NEGRISOLI, E., ROSSI, C.V. \& OLIVEIRA, C.P. 2010. Efeitos de períodos de permanência de clomazone + hexazinona no solo e na palha de cana-de-açúcar antes da ocorrência de chuvas na eficácia de controle de plantas daninhas. Planta Daninha, 28(1): 197-205. http://dx.doi.org/10.1590/S0100-83582010000100023

CARVALHO, J.L.N., NOGUEIROL, R.C., MENANDRO, L.M.S., BORDONAL, R.O., BORGES, C.D., CANTARELLA, H. \& FRANCO, H.C.J. 2016. Agronomic and environmental implications of sugarcane straw removal: a major review. GCB Bioenergy, 9: 1181-1195. http://dx.doi.org/10.1111/gcbb.12410

CORREIA, N.M., CAMILO, E.H. \& SANTOS, E.A. 2013. Sulfentrazone efficiency on Ipomoea hederifolia and Ipomoea quamoclit as influenced by rain and sugarcane straw. Planta Daninha, 31(1): 165-174. http://dx.doi.org/10.1590/S010083582013000100018

DANG, A., SILBURN, M., CRAIG, I., SHAW, M. \& FOLEY, J. 2016. Washoff of residual photosystem II herbicides from sugar cane trash under a rainfall simulator. J. Agr. Food Chem., 64(20): 3967-3974. http://dx.doi.10.1021/acs.jafc.5b04717

DAVIS, A.M., THORBURN, P.J., LEWIS, S.E., BAINBRIDGE, Z.T., ATTARD, S.J., MILLA, R. \& BRODIE, J.E. 2013. Environmental impacts of irrigated sugarcane production: Herbicide run-off dynamics from farms and associated drainage systems. Agr. Ecosyst. Environ., 180: 123-135. http://dx.doi. org/10.1016/j.agee.2011.06.019

DEFERSHA, M.B. \& MELESSE, A.M. 2012. Effect of rainfall intensity, slope and antecedent moisture content on sediment concentration and sediment enrichment ratio. Catena, 90: 47-52. http://dx.doi.org/10.1016/j.catena.2011.11.002

GARBIATE, M.V., VITORINO, A.C.T., TAMASINI, B.A., BERGAMIM, A.C. \& PANACHUKI, E. 2011. Erosão em entre sulcos em área cultivada com cana crua e queimada sob colheita manual e mecanizada. Rev. Bras. Cienc. Solo, 35(6): 2145-2155. http://dx.doi.org/10.1590/S0100-06832011000600029

GIORI, F.G., TORNISIELO, V.L. \& REGITANO, J.B. 2014. 
The role of sugarcane residues in the sorption and leaching of herbicides in two tropical soils. Water Air Soil Poll., 255: 19351938. http://dx.doi.org/10.1007/s11270-014-1935-8

GOMIDES, L., SINGER, H., STEPHAN, R., MULLER, S.R., SCHWARZENBACH, R.P. \& STAMM, C, 2008. Source area effects on herbicide losses to surface waters - A case study in the Swiss Plateau. Agr. Ecosyst. Environ., 128: 177-184. http:// dx.doi.org/10.1016/j.agee.2008.06.014

IBGE (BRAZILIAN INSTITUTE OF GEOGRAPHY AND STATISTICS). 2018. Sistema IBGE de Recuperação Automática - SIDRA.

INMETRO (NATIONAL INSTITUTE OF METROLOGY, QUALITY AND TECHNOLOGY). 2018. Orientação sobre validação de métodos analíticos. DOQ-CGCRE-008 Revisão 07. http://www.inmetro.gov.br/Sidoq/Arquivos/ CGCRE/DOQ/ DOQ-CGCRE-8_07.pdf

LEFRANCQ, M., JADAS-HÉCART A., LA JEUNESSE, I., LANDRY, D. \& PAYRAUDEAU, S. 2017. High frequency monitoring of pesticides in runoff water to improve understanding of their transport and environmental impacts. Sci. Total Environ., 587: 75-86. http://dx.doi.org/10.1016/j.scitotenv.2017.02.022

LOCKE, M.A. \& BRYSON, C.T. 1997. Herbicide-soil interaction in reduced tillage and plant residue management systems. Weed Sci., 45(2): 307-320. http://dx.doi.org/10.1017/S0043174500092882

MARENGO, R.J., JONES, R., ALVES, L.M. \& VALVERDE, M.C. 2009. Future change of temperature and precipitation extremes in South America as derived from the PRECIS regional climate modeling system. Int. J. Climatol., 29: 2241-2255. http://dx.doi. org/10.1002/joc. 1863

MASTERS, B., ROHDE, K., GURNER, N. REID, D. 2013. Reducing the risk of herbicide runoff in sugarcane farming through controlled traffic and early-banded application. Agr. Ecosyst. Environ., 180: 29-39. http://dx.doi.org/10.1016/j. agee.2012.02.001

MÜLlER, K., TROLOVE, M., JAMES, T.K. \& RAHMAN, A. 2004. Herbicide loss in runoff: effects of herbicide properties, slope, and rainfall intensity. Aust. J. Soil Res., 42(1): 17-27. http://dx.doi.org/10.1071/SR03090

PAES, L.A.D. \& OLIVEIRA, M.A. 2005. Potential trash biomass of the sugar cane plant. In: Hassuani, S.J., Leal, M.R.L.V. \& Macedo, I.C. (eds) Biomass power generation: sugar cane bagasse and trash. Piracicaba-SP: PNUD-CTC, pp. 19-23.

PEREIRA-JUNIOR, E.V., GIORI, F.G., NASCIMENTO, A.L., TORNISIELO, V.L. \& REGITANO, J.B. 2015. Effects of soil attributes and straw accumulation on the sorption of hexazinone and tebuthiuron in tropical soils cultivated with sugarcane. J. Environ. Sci. Heal. B, 50(4): 238-246. http://dx.doi.org/10.108 0/03601234.2015.999588

PPDB (PESTICIDE PROPERTIES DATABASE). 2016. University of Hertfordshire.

PRICHARD, T., TROIANO, J., MARADE, L., GUO, F. \& CANEVARI, M. 2005. Movement of diuron and hexazinone in clay soil and infiltrated pond water. J. Environ. Qual., 34(6): 2005-2017. http://dx.doi.org/10.2134/jeq2004.0253
ROSSI, C.V.S., VELINI, E.D., LUCHINI, L.C., NEGRISOLI, E., CORREA, M.R., PIVETTA, J.P., COSTA, A.G.F. \& SILVA, F.M.L. 2013. Dinâmica do herbicida metribuzin aplicado sobre palha de cana-de-açúcar (Saccarum officinarum). Planta Daninha, 31(1): 223-230. http://dx.doi.org/10.1590/S010083582013000100024

SANTOS, H.G., JACOMINE, P.K.T., ANJOS, L.H.C., OLIVEIRA, V.A., OLIVEIRA, V.B., COELHO, M.R., LUMBREAS, J.F. \& CUNHA, T.J.F. 2006. Sistema brasileiro de classificação de solos. Rio de Janeiro: Embrapa Solos. 306p.

SCORZA JÚNIOR, R.P. 2015. Método multirresíduo para determinação dos herbicidas ametrina, diuron, hexazinona, imazapique e sulfentrazona em amostras de águas superficiais. Dourados-MS: Embrapa Agropecuária Oeste. 6p. (Comunicado Técnico 205).

SHIPITALO, M.J. \& OWENS, L.B. 2006. Tillage system, application rate, and extreme event effects on herbicide losses in surface runoff. J. Environ. Qual., 35(6): 2186-2194. http://dx.doi. org $/ 10.2134 /$ jeq2005.0476

SILBURN, D.M., FOLEY, J.L. \& DEVOIL, R.C. 2013. Managing runoff of herbicides under rainfall and furrow irrigation with wheel traffic and banded spraying. Agr. Ecosyst. Environ., 180: 40-53. http://dx.doi.org/10.1016/j.agee.2011.08.018

SILVA, G.R.V., SOUZA, Z.M., MARTINS, M.V., BARBOSA, R.S. SOUZA, G.S. 2012. Soil, water and nutrient losses by interril erosion from green cane cultivation. Rev. Bras. Cienc. Solo, 36(3): 963-970. http://dx.doi.org/10.1590/S0100-06832012000300026

SIMONI, F., VICTORIA-FILHO, R., SAN-MARTIN, H.A.M., SALVADOR, F.L., ALVES, A.S.R. \& BREMER-NETO, H. 2006. Eficácia de imazapic e sulfentrazone sobre Cyperus rotundus em diferentes condições de chuva e palha de canade-açúcar. Planta Daninha, 24(4): 769-778. http://dx.doi. org/10.1590/S0100-83582006000400018

TONIÊTO, T.A.P., DE PIERRI, L., TORNISIELO, V.L. \& REGITANO, J.B. 2016. Fate of tebuthiuron and hexazinone in green-cane harvesting system. J. Agr. Food Chem., 64(20): 3960-3966. http://dx.doi.org/10.1021/acs.jafc.5b04665

ULRICH, U., DIETRICH, A. \& FOHRER, N. 2013. Herbicide transport via surface runoff during intermittent artificial rainfall: A laboratory plot scale study. Catena, 101: 38-49. http://dx.doi. org/10.1016/j.catena.2012.09.010

VAZ, L.R.L. 2016. Perdas de hexazinona e diuron por escoamento superficial em sistemas de cana crua. MSc. Dissertation. Escola Superior de Agricultura “Luiz de Queiroz", Universidade de São Paulo, Piracicaba, 73p.

ZHANG, X.C., NORTON, L.D. \& HICKMAN, M. 1997. Rain pattern and soil moisture content effects on atrazine and metolachlor losses in runoff. J. Environ. Qual., 26(6): 1539-1547. http:// dx.doi.org/10.2134/jeq1997.00472425002600060013x

ZHAO, N., YU, F.L.I.C., ZHANG, L., LIU, J., MU, W. \& WANG, H. 2015. Soil moisture dynamics and effects on runoff generation at small hillslope scale. J. Hydrol. Eng., 20(7): 0501-4024. http:// dx.doi.org/10.1061/\%28ASCE\%29HE.1943-5584.0001062 